\title{
Academics Alone Together: \\ Liberal Arts Graduate Students' Writing Networks
}

\author{
Mary Hedengren \\ University of Houston - Clear Lake \\ Hannah V. Harrison \\ University of Texas at Austin
}

\begin{abstract}
Graduate writers who develop networks of writing are positioned to enter into the larger discourse community during and after graduate work. Our study surveyed graduate writers in the humanities about their sources of writing feedback and how much they use and trust those sources. The results indicate that graduate students do employ a variety of sources and strategically assess when and how to use those sources. Still, many graduate students do not get frequent feedback on their writing, and others believe "we take what we get" in writing feedback. Student services that serve graduate students should work in conjunction with graduate program administrators and advisors to encourage students to develop effective networks of writing feedback, including important peer networks.
\end{abstract}

\section{Introduction}

Graduate student writers are under enormous pressure to successfully complete quality writing projects. In addition to writing theses and dissertations, many graduate students are also expected to write and publish reviews, articles and conference presentations (Kamler \& Thomson, 2014; Lee \& Aitchison, 2011).

In recent years, international scholars of composition, psychology, and higher education have begun to plumb the reasons why some graduate students become overwhelmed with their writing tasks and why some succeed. Most of the solutions from the American, Canadian, and Australian educational systems focus on improving graduate advising (Baird, 1995; Council of Graduate Schools, 2008; Eyres, Hatch, Turner, \& West, 2001; Gardner \& Barnes, 2014; Gold \& Dores, 2001; Lovitts, 2001; Nettles \& Millett, 2006). Certainly, the advisor is an important figure in a graduate writer's life and advisors are often critical sources for writing help ranging from time 
management practices (Sweitzer, 2009) to disciplinary conventions (Eyres et al., 2001). However, few faculty members receive training in how to advise on a dissertation (Amundsen \& McApline, 2009; Starke-Meyerring, 2009). This leads some dissertation advisors to focus only on content advising because they believe they don't have the time, ability or interest in teaching writing skills (Aitchison \& Pare, 2012; Catterall, Ross, Aitchison, \& Burgin, 2011).

Humanities graduate students especially may feel at sea in writing a dissertation, unlike their science or engineering peers who experience the situated learning (Lave \& Wenger, 1991) of co-authored publications and directed labs. The humanities are what Becher and Trowler (2001) call rural, meaning that very few researchers work in the same area, so graduate students in humanities set out their own homestead, often in areas distinct from their advisors'. Sharon Parry's 2007 study discovered that humanities graduate students were "regarded more as new colleagues by supervisors" (p. 55) and new colleagues, unlike apprentices, are expected to be self-sustaining. As a result, perhaps, some studies indicate that graduate students in the humanities and liberal arts are more likely than graduate students in sciences and applied arts to leave graduate school without receiving a degree (Ehrenburg, Zuckerman, Groen, \& Brucker, 2009; National Research Council, 1996).

In order to succeed, these humanities graduate students are looking beyond their advisor for writing feedback. As Bieber and Worley (2006) put it, "We have come to understand that the role of the graduate mentor is neither as central nor as all-encompassing and influential as commonly believed" (p. 1010). Many graduate students are already reaching beyond their advisor. When McAlpine and Amundsen (2011) tracked Canadian graduate student writers with monthly logs for two and a half years, their participants reported that $20 \%$ of their writing interactions were with their supervisors. A further $20 \%$ were with family and friends, and $15 \%$ were with peers in the doctoral program. Certainly, "the peer is a defining figure in research practice" (Boud \& Lee, 2005, p. 510) - think, for example, of the process of academic peer review-yet we may be surprised at the variety and prevalence of resources beyond the faculty advisor.

While much of the literature on graduate student success focuses on the importance of the advisor, the current study seeks to explore a full holistic network of graduate writing support, one that certainly includes engaged advisors, but also peer colleagues, family and friends, and professional graduate writing resources. In doing so, the authors seek not to downplay the role of the advisor, but to emphasize the diverse networks of writing support that graduate students employ.

No scholar, so to speak, is an island, and successful written scholarship depends rich networks of editors, reviewers, and colleagues, as the above review of the literature has shown. Our empirical results demonstrate that humanities graduate students rely on a network of scholarly and personal relationships to get feedback on their writing. Advisors are important for humanities graduate students; they are not, however, enough. Graduate student writers receive different types of feedback from the different members of their writing feedback support networks. Our findings also lead to practical interventions for administrators and student service providers who wish to see their graduate students build robust writing networks. If, as our research indicates, successful 
humanities graduate students already draw on many sources for writing feedback, we need to consciously teach them how to use those networks effectively.

\section{Methods}

After receiving IRB approval, we recruited and collected data on the frequency, type, and quality of feedback from 115 liberal arts graduate students from a state flagship university with a long history of graduate education and institutional research. The majority $(n=66 ; 57 \%)$ of participants were dissertating doctoral candidates, though participants included pre-masters $(n=22 ; 19 \%)$ and post-masters $(n=27 ; 24 \%)$ students still in coursework. Our work is exploratory and investigative in nature; we do not intend for this study or its results to be generalizable.

Data were generated using a mixed-methods approach with three modes: a survey questionnaire, a focus group, and semi-structured interviews. The questionnaire was administered first, followed by a convenience sample of qualitative interviews to triangulate with the questionnaire data. Based on student availability, interviews were conducted in one-on-one personal settings, via email, and in one group interview with half a dozen graduate students. In all, 14 students (12\%) from the survey were interviewed. Each follow-up interview that took place in person was semi-structured; each began with the same questions addressed in the questionnaire, but deviated based on the conversation's organic progression. Interview sessions were taperecorded and recordings were transcribed. Results were consistent across interview formats, questionnaires, and media.

In this study, we employ specific vocabulary terms: When we discuss data about the sources offeedback, we refer to the people - groups or individuals - who provided feedback to the graduate student writers. The sources of feedback respondents we considered include dissertation advisors, classmates and colleagues, writing group members, writing consultants, non-advisor instructors, editors or reviewers, family and friends, and an unspecified other. The term form of feedback refers to questions and responses about the modes in which feedback was delivered, specifically written marginal comments, written end comments, and spoken feedback. We refer to type of feedback to discuss responses about an aspect of the student's writing that ranges across a spectrum. This spectrum is often referred to in writing pedagogies as a spectrum of higher-order (such as content and analysis) to lower-order concerns (such as grammar and mechanics).

\section{Results}

The main finding of our study shows that graduate students do get writing feedback from sources beyond their advisors and that students are savvy about what kind of writing feedback they get from their sources. Advisors are still important, but classmates and colleagues, other instructors, writing groups, and various other people form the networks these graduate students use in improving their academic writing. 


\section{Sources of Feedback}

Table 1 shows the overall composition of feedback sources our participants reported in the initial survey. It is important to note that the percentages will not sum to $100 \%$ because they reflect the percentage of graduate students who use that source, and students, as we cannot emphasize enough, use multiple sources of feedback. For instance, a graduate student who has formal meetings with an advisor and participates in a writing group will be counted in 2 rows: as part of the $79 \%$ of participants who work with an advisor and as part of the $23 \%$ who meet with a writing group. Figure 1 demonstrates the relative weight of each source in comparison to all other sources. In this formulation, advisors represent $23.3 \%$ of all feedback mentioned (from a total of 390 mentioned sources). In the following section, we will explore these data and the nuances of how graduate students use various feedback sources to improve their writing.

\section{Table 1}

Graduate Students' Reported Sources of Feedback on Writing

\begin{tabular}{lcc}
\hline \hline Sources of Feedback & $n$ & $\%$ \\
\hline Advisor & 91 & $79 \%$ \\
Classmate and colleagues & 94 & $82 \%$ \\
Family and friends & 65 & $57 \%$ \\
Instructor (not advisor) & 64 & $56 \%$ \\
Writing group & 34 & $30 \%$ \\
Editor or reviewer & 27 & $23 \%$ \\
Writing consultant & 9 & $8 \%$ \\
\hline \hline
\end{tabular}

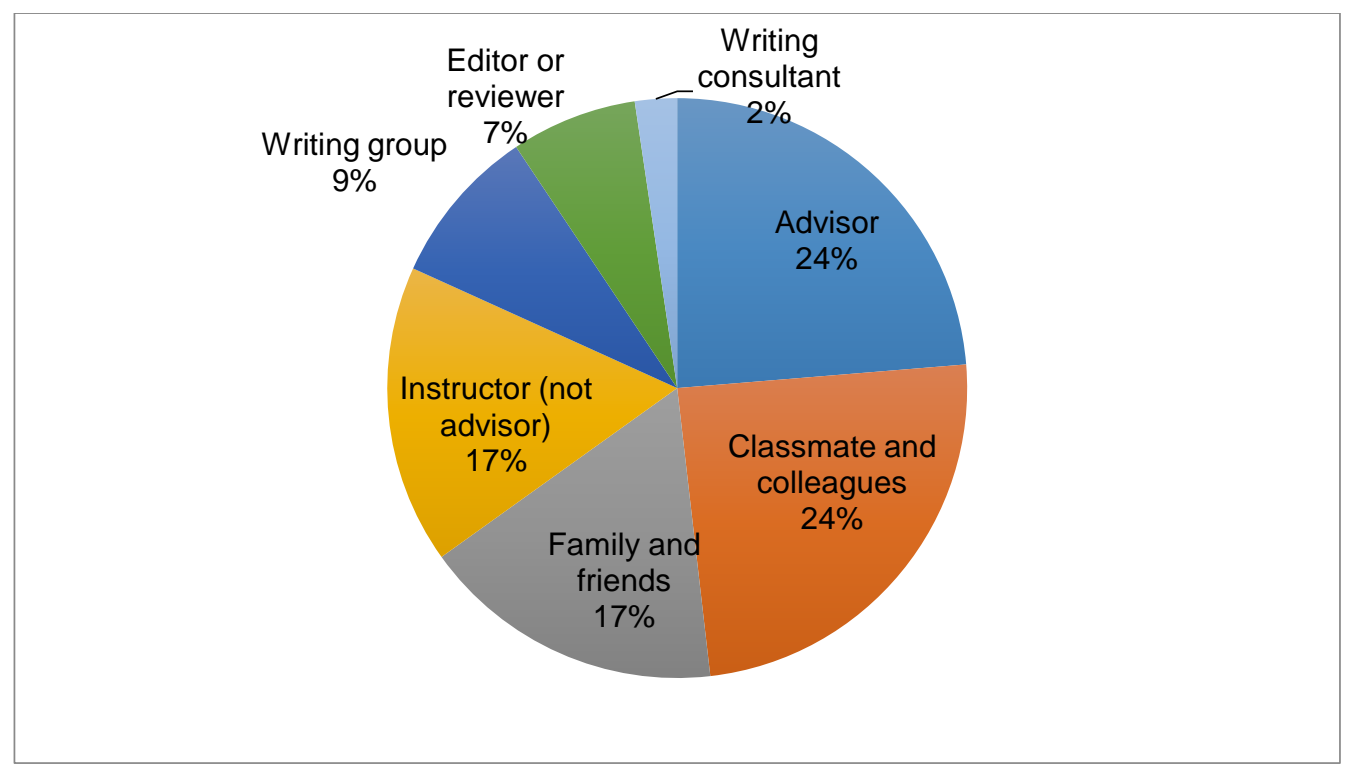

Figure 1. Sources of reported feedback in relation to each other. 
We are not arguing that advisors aren't important to graduate students. Certainly advisors are important: for example, $80 \%$ of participants indicated that they had received feedback from their formal advisor during the last two years, a number that jumps to $92 \%$ when restricted to current doctoral candidates. But other sources are also important. The first row in Table 2 represents the most advanced graduate students - those doctoral candidates writing a dissertation. Row 2 represents all the other graduate students, including those who have already received their masters degree. Row 3 represents only beginning graduate students, those who have not fulfilled the requirements for the masters. The final row reflects all graduate students. Other tables in this study aggregate graduate student responses for simplicity's sake, but we recognize that beginning graduate students may experience the various sources of writing feedback differently from their more advanced colleagues.

\section{Table 2}

Graduate Students' Reported Sources of Feedback by Level of Graduate Study

\begin{tabular}{|c|c|c|c|c|c|c|c|c|c|c|c|c|c|c|}
\hline \multirow[b]{2}{*}{ Level of Study } & \multicolumn{2}{|c|}{ Advisor } & \multicolumn{2}{|c|}{$\begin{array}{c}\text { Classmate } \\
\text { and } \\
\text { colleagues }\end{array}$} & \multicolumn{2}{|c|}{$\begin{array}{l}\text { Family } \\
\text { and } \\
\text { friends }\end{array}$} & \multicolumn{2}{|c|}{$\begin{array}{l}\text { Instructor } \\
\text { (not advisor) }\end{array}$} & \multicolumn{2}{|c|}{$\begin{array}{l}\text { Writing } \\
\text { group }\end{array}$} & \multicolumn{2}{|c|}{$\begin{array}{l}\text { Editor or } \\
\text { reviewer }\end{array}$} & \multicolumn{2}{|c|}{$\begin{array}{l}\text { Writing } \\
\text { consultant }\end{array}$} \\
\hline & $n$ & $\%$ & $n$ & $\%$ & $n$ & $\%$ & $n$ & $\%$ & $n$ & $\%$ & $n$ & $\%$ & $n$ & $\%$ \\
\hline $\begin{array}{l}\text { Dissertating } \\
\text { Doctoral } \\
\text { Candidates }\end{array}$ & 61 & 92 & 52 & 79 & 38 & 58 & 30 & 45 & 26 & 39 & 19 & 29 & 6 & 11 \\
\hline $\begin{array}{l}\text { Other } \\
\text { Doctoral and } \\
\text { Pre- Masters } \\
\text { Students }\end{array}$ & 31 & 62 & 42 & 84 & 27 & 54 & 34 & 68 & 8 & 16 & 8 & 16 & 3 & 6 \\
\hline $\begin{array}{l}\text { Pre-Masters } \\
\text { students }\end{array}$ & 8 & 41 & 17 & 77 & 11 & 50 & 17 & 77 & 3 & 14 & 3 & 14 & 2 & 9 \\
\hline $\begin{array}{l}\text { All Graduate } \\
\text { Students }\end{array}$ & 91 & 79 & 94 & 82 & 65 & 57 & 64 & 56 & 34 & 30 & 27 & 23 & 9 & 8 \\
\hline
\end{tabular}

Informal writing support is common. Closely trailing behind advisors, classmates and colleagues are important to graduate students, especially at two crucial pinch points: at the beginning and end of graduate study. Seventy-seven percent of beginning graduate students (students who have not completed their masters requirements) said that they had received writing help from classmates or colleagues sometime in the past two years. One might be tempted to think that, because doctoral candidates are more experienced, they would no longer rely on their peers, but as graduate students progress, there is essentially no change in the use of classmates and colleagues as writing support: Seventy-nine percent of dissertating graduate students indicate that they had turned to their peers for writing help. Informal sources of feedback become more important as graduate students lose the structure of the classroom.

Among all graduate students, there is a large drop between the first two categories of advisors (79\%) and classmates (82\%) and the next highest source: family and friends (57\%). 
Around half of all groups of graduate students consistently report going to family and friends-in fact, $50 \%$ of beginning graduate students go to family at friends and $58 \%$ of advanced graduate students do so. It may be that the beginning students receive feedback from other, more structured sources, or it may be that beginners are too self-conscious of their new academic roles to ask their closest, and least academic, sources for help. Even advanced graduate students, after years of study and building up networks with scholars, continue to turn to family and friends at high rates.

Doctoral candidates are far less likely to have received help by an instructor, presumably because they are no longer in course work and are thus not getting feedback on writing required for their seminar. However, $45 \%$ of doctoral candidates do report having received feedback from a non-advisor instructor in the past two years, making this source the fourth largest category of writing feedback for doctoral candidates. Graduate students unlikely to be taking courses are still drawing on the feedback of instructors, possibly instructors that they had for previous classes. But the written comments of respondents indicate they wish that they had more feedback from instructors. Wrote one graduate student, "Most feedback from instructor is limited to their class, [sic] I wish there was an opportunity for instructors to give feedback for content created for unrelated courses."

While there may not be much structure to encourage students to seek out feedback and support from non-advisor instructors, advanced graduate students seek other forms of feedback once classwork has ended: Thirty-nine percent of doctoral candidates report seeking and receiving support from a writing group in the last two years, up from $14 \%$ of pre-masters graduate students. Writing groups can be a space to practice the give-and-take of feedback networks in an intentional space removed from the power dynamics of approaching a professor.

\section{Frequency of Feedback by Form}

We asked participants to list the sources from whom they had received feedback in the last two years and, after all, just one incident of feedback in two years isn't much help. Feedback frequency and form may also impact the students' experience: for example, an advisor might often provide spoken feedback on a draft, but never give written comments. Table 3 demonstrates the average frequency, on a Likert scale of 0-6 (never to daily), that graduate students in our sample received different forms feedback from different sources. Most of our participants report getting feedback from advisors at a relatively frequent rate (somewhere, on average, between 2 [monthly] and 3 [2-3 times a month]), but even that feedback comes at less regular intervals than the frequently meeting, but less popular, writing groups. Writing groups shine as an example of students receiving frequent written and spoken feedback, which we suspect results from participants meeting at a set time- often, but not always, in the weekly formal writing groups offered by the University Writing Center. Sadly, only $29 \%$ of our respondents reported using writing groups as a source of feedback. After writing groups and advisors, classmates and nonadvisor instructors provide frequent feedback, especially in the spoken feedback category. At the other end of the spectrum, journal reviewers and writing consultants provide only occasional feedback, and thus are also the least frequent sources of feedback in our sample. 
Table 3

Graduate Student Reported Frequency of Writing Feedback

\begin{tabular}{lccccc}
\hline \hline & $n$ & $\begin{array}{c}\text { Written } \\
\text { comments } \\
\text { (marginal) }\end{array}$ & $\begin{array}{c}\text { Written } \\
\text { comments } \\
\text { (end comment) }\end{array}$ & $\begin{array}{c}\text { Spoken } \\
\text { comments }\end{array}$ & $\begin{array}{c}\text { Average } \\
\text { frequency } \\
\text { across all forms }\end{array}$ \\
\hline Advisor & 92 & 2.88 & 2.70 & 3.06 & 2.88 \\
Classmate and colleagues & 94 & 2.40 & 2.05 & 2.86 & 2.44 \\
Family and friends & 65 & 2.04 & 1.65 & 2.68 & 2.12 \\
Instructor (not advisor) & 64 & 2.46 & 2.21 & 2.55 & 2.41 \\
Writing group & 34 & 3.45 & 3.25 & 3.4 & 3.37 \\
Editor/reviewer & 27 & 1.74 & 2.05 & 1.39 & 1.73 \\
Writing consultant & 9 & 2.00 & 1.67 & 2.00 & 1.89 \\
\hline \hline
\end{tabular}

*Average frequency of feedback 0-6 from never (0), less than once a month (1), once a month (2), 2-3 times a month (3), once a week (4), 2-3 times a week (5), and daily (6).

\section{Type of Feedback}

Our data show that feedback from advisors and instructors is most commonly focused on content, while colleagues, family, and friends are consulted more frequently for proofreading and clarity issues. As one participant observed:

Sometimes ... if I'm really bogged down in it and I can't tell if I'm making sense at all, I'll send it to ... my dad and be like, 'Just read it and tell me as somebody who has no idea what I'm talking about ... if I made a clear point here' and that's usually useful to a limited extent. But when it comes to my dad versus my professor, I will choose the professor's feedback.

This statement demonstrates that this advanced graduate student has recognized the relative advantages of sending her work to her dad as opposed to sending it to a more authoritative source that might get bogged down in the content. The distinction between clarity and content, or lowerorder and higher-order concerns, informs how graduate students use their sources. Table 4 demonstrates that higher-order issues like concept and content are the purview of advisors, while dads and other informal relationships are frequently employed to help with grammar and proofreading. 
Table 4

Graduate Student Agreement with Statements Relating to Types of Feedback.

\begin{tabular}{lcccc}
\hline \hline & & \multicolumn{3}{c}{ Agreement with Statement (\%) } \\
\cline { 3 - 5 } & $n$ & $\begin{array}{c}\text { I go to [resource] for } \\
\text { help with big-picture } \\
\text { conceptual elements in } \\
\text { my writing. }\end{array}$ & $\begin{array}{c}\text { We spend more time } \\
\text { talking about content } \\
\text { than writing. }\end{array}$ & $\begin{array}{c}\text { The feedback I get } \\
\text { from [resource] } \\
\text { usually focuses on } \\
\text { grammar or } \\
\text { proofreading }\end{array}$ \\
\hline Advisor & 92 & 84.52 & 74.76 & 26.45 \\
Classmate and colleagues & 94 & 65.82 & 64.77 & 40.85 \\
Family and friends & 65 & 57.13 & 48.52 & 60.83 \\
Instructor (not advisor) & 64 & 72.33 & 70.31 & 25.43 \\
Writing group & 34 & 62 & 52.79 & 35.24 \\
Editor/reviewer & 27 & 31.67 & 77.94 & 49.33 \\
Writing consultant & 9 & 42.33 & 47 & \\
\hline \hline
\end{tabular}

*Average agreement with the statements on a scale of $0-100$ where 0 equals total disagreement, 50 is neutral, and 100 is total agreement.

As authorities in their subject areas, advisors and instructors often provide feedback regarding the conceptual accuracy of the writing. Their content expertise is reflected in their contributions to the higher-order issues graduate students have about their writing. When it comes to lower-order concerns of grammar and punctuation, family and friends are the go-to sources. Respondents reported that even their writing consultants and writing groups, often stigmatized as focusing on lower-order concerns free from disciplinary content or genre knowledge, avoid persistently giving feedback on grammar. Grammar and punctuation, however, are not insignificant concerns, especially for many international students learning to write in American Academic English. That family and friends are the primary resource for grammar-intensive feedback may suggest that graduate students are unwilling to "bother" institutional resources for help improving grammar.

\section{Satisfaction with Feedback}

Satisfaction is a sometimes troubling metric in educational research. Athiyaman (1997) pointed out that satisfaction is not synonymous with service quality perception and that this may be particularly problematic in educational research as satisfaction must change over time, for example, as a student comes to see the value of a challenging course. And, often, students ignore or minimize dissatisfaction, to our institutional and theoretical detriment, especially for student services (Hedengren \& Lockerd, 2017). For our purposes here, we are defining satisfaction in two 
ways: how well the source responded to the needs of the graduate writer (responsiveness) and how effective the source was on improving the writing process or product (productivity). While responsive and productive support may seem requisite elements of satisfaction in many aspects of business and education, some graduate students are not convinced that they are entitled to either.

Most of the students in our survey and interview were comfortable for asking for a certain type of help, but the perception among some of participants of our study is that seeking and getting a certain kind feedback from a source may be difficult. One focus group respondent said that she found it "hard asking f[or] feedback from [an] advisor because I want all of the different levels of feedback from this one resource." She knew that she should find other sources to provide her with lower-order feedback, she explained, but she didn't know where else to go besides her advisor. One survey respondent was even perplexed about why we were asking whether he felt he got the kind of feedback he needed from his advisor: "We don't request a type of feedback," he commented. "We're told what kind of feedback to expect." In another place in the survey, he wrote, "I've never known a grad student to request a type of feedback. Usually we take what we get. Not sure if the person making this form really gets the power structures." According to these students, beggars in the academic world can't be choosers.

Despite the occasional cynicism, our participants were, on average, satisfied with how responsive their sources were when asked about two indicators: whether their source will give them the type of feedback they request and, inversely, whether they wish their source could give them more specific or direct advice. Advisors fare well in these indicators overall (see Table 5). Participants, on average, agree that their advisors give them the kind of feedback they request, and were only slightly less than neutral about wanting more specific advice. While extremes may exist, overall, graduate students seem satisfied with their advisors' feedback. And as in frequency

Table 5

Graduate Student Agreement to Statements about Feedback Responsiveness.

\begin{tabular}{lccc}
\hline \hline & & \multicolumn{2}{c}{ Agreement with Statement (\%) } \\
\cline { 3 - 4 } & $n$ & $\begin{array}{c}\text { My [resource] will give me } \\
\text { the type of feedback that I } \\
\text { request. }\end{array}$ & $\begin{array}{c}\text { I wish my [resource] would } \\
\text { give me more direct or } \\
\text { specific advice. }\end{array}$ \\
\hline Advisor & 92 & 68.53 & 48.2 \\
Classmate and colleagues & 94 & 68.1 & 42.68 \\
Family and friends & 65 & 65.4 & 32.94 \\
Instructor (not advisor) & 64 & 58.69 & 62 \\
Writing group & 34 & 74.35 & 48.63 \\
Editor/reviewer & 27 & 64.13 & 32.43 \\
Writing consultant & 9 & 75 & 29.5 \\
\hline
\end{tabular}

*Average agreement with the statements on a scale of 0-100 where 0 equals total disagreement, 50 is neutral, and 100 is total agreement. 
of feedback, classmates and colleagues and family and friends trail close on the heels of advisor satisfaction. Formalized peer feedback, writing groups, and consultants are also reported as highly responsive to graduate writing requests for feedback, despite the relatively low numbers of respondents who use these sources.

Instructors who were not a formal advisor fared the worst by these measures, with lower levels of responsiveness and higher desire for more specific advice than even potentially remote editors and reviewers.

A few caveats on the results presented in Table 5 are necessary to explain. Many of the writing groups and consultants at our institution are based in the writing center and, accordingly, the groups and consultations use writing center pedagogical practices. Such practices typically prioritize a student writer's self-stated agenda over the concerns a consultant or writing group member may have (North, 1984). If the writing center is sponsoring and training those who provide feedback, it is unsurprising that writers see patterns of writing center-influenced feedback. An alternative conclusion suggests that students are used to thinking of consultants and writing groups as sources of feedback who are "working for them"; instead of feeling as though they are told"” what kind of feedback to expect from an advisor, graduate writers may have more confidence asking for what they want from a writing group or consultant.

At the other end of the extremes, instructors rated highest (62\%) in regards to the respondents' wish for more direct or specific advice. Again, there may be a difference between instructors who are approached outside of a class and those who give feedback as part of a class. Students still in coursework are more eager for direct advice, as shown in Table 6. Advanced graduate writers may seek out preferred instructors from whom they solicit feedback, changing the relationship from a hierarchy to a relationship, where they can more comfortably request specific feedback.

\section{Table 6}

Graduate Student Agreement with Statements about Responsiveness of Non-advisor Instructor Feedback

\begin{tabular}{lccc}
\hline \hline & & \multicolumn{2}{c}{ Agreement with Statement (\%) } \\
\cline { 3 - 4 } & $n$ & $\begin{array}{c}\text { My instructor (not advisor) } \\
\text { will give me the type of } \\
\text { feedback that I request. }\end{array}$ & $\begin{array}{c}\text { I wish my instructor (not } \\
\text { advisor) would give me more } \\
\text { direct or specific advice. }\end{array}$ \\
\hline $\begin{array}{l}\text { Dissertating Graduate Students } \\
\text { (Doctoral Candidates) }\end{array}$ & 66 & 56.78 & 53.29 \\
$\begin{array}{l}\text { Students in Coursework } \\
\text { Total }\end{array}$ & 49 & 61 & 70.3 \\
\hline
\end{tabular}

*Average agreement with the statements on a scale of 0-100 where 0 equals total disagreement, 50 is neutral, and 100 is total agreement. 
We also asked graduate students to rank their perception of how the different resources impacted both the process (i.e., "Getting feedback...helps me progress") and the product (i.e., "My academic writing is better after getting feedback") of their writing. The results are found in Table 7. Advisors rank high as resources that improve process and product. Writing consultants, too, rank high. At the lower end of the spectrum, our participants were less certain of the value of family and friends' feedback, especially on improving the product. There may be a relationship between the institutional authority of the source and confidence in their feedback. In measuring the degree of trust our participants have for their sources, advisors came up on top, followed by consultants, and instructors - all officially designated positions. Peer groups fared well overall, but less favorably than the professionals.

\section{Table 7}

Graduate Student Agreement with Statements of Productivity in Writing Feedback

\begin{tabular}{lcccc}
\hline \hline & & \multicolumn{3}{c}{ Agreement with Statement (\%) } \\
\cline { 3 - 5 } & $n$ & $\begin{array}{c}\text { Getting feedback } \\
\text { from my [resource] } \\
\text { helps me progress in } \\
\text { my academic } \\
\text { writing. }\end{array}$ & $\begin{array}{c}\text { I notice my } \\
\text { academic writing is } \\
\text { better after getting } \\
\text { feedback from [this } \\
\text { Source of Feedback }\end{array}$ & $\begin{array}{c}\text { I trust my [resource] } \\
\text { to give me good } \\
\text { advice on writing. }\end{array}$ \\
\hline Advisor & 92 & 87.19 & 85.31 & 89.54 \\
Classmate and colleagues & 94 & 77.64 & 71.41 & 75.86 \\
Family and friends & 65 & 65.96 & 58.54 & 68.72 \\
Instructor (not advisor) & 64 & 80.58 & 74.22 & 77.56 \\
Writing group & 34 & 79 & 75.6 & 70.26 \\
Editor/reviewer & 27 & 79.94 & 77.78 & 86.67 \\
Writing consultant & 9 & 86 & 87.33 & 73 \\
\hline \hline
\end{tabular}

*Average agreement with the statements on a scale of 0-100 where 0 equals total disagreement, 50 is neutral, and 100 is total agreement.

\section{Emotional Response to Feedback}

Getting feedback on writing isn't just a mechanical process, though: it's also an emotional one. Table 8 describes emotional response to the writing feedback graduate students receive. The first three columns relate negative emotions, so a low agreement would indicate a lack of dissatisfaction. These first three columns, then, would ideally have very low numbers. Column 4 describes the degree that the respondents believe they get a good mix of positive and negative 
comments, and provides a mirror to the preceding question about feedback being unnecessarily harsh.

Our respondents, as a whole, don't appear to have widespread emotional frustrations with the feedback they get, but it is worth noting that students rank advisors and instructors with the highest level of agreement with the statement that they don't "take [a student] seriously as an academic writer". Faculty also rank high for giving "unnecessarily harsh" feedback, but it is interesting to note that classmates and colleagues are ranked even higher for being unduly critical. No source is perfect, and advisors and instructors were rated below writing groups and consultants in providing a "good mix of praise and suggestions."

Overall, though, students in our study seem to be relatively comfortable asking for help from advisors, and report that the classmates, instructors, and family and friends are the most difficult sources to approach for feedback. That may be because these sources lack official institutional endorsement, so students have a harder time knowing how to access these resources.

\section{Table 8.}

Graduate Student Agreement with Statements about Emotional Response to Feedback

\begin{tabular}{|c|c|c|c|c|c|}
\hline \multirow[b]{2}{*}{ Source of Feedback } & \multirow[b]{2}{*}{$n$} & \multicolumn{4}{|c|}{ Agreement with Statement (\%) } \\
\hline & & $\begin{array}{l}\text { I have a hard } \\
\text { time feeling } \\
\text { comfortable } \\
\text { asking for } \\
\text { feedback from } \\
\text { [this resource]. }\end{array}$ & $\begin{array}{l}\text { When I work } \\
\text { with [this } \\
\text { resource], I } \\
\text { don't feel like } \\
\text { they take me } \\
\text { seriously as an } \\
\text { academic } \\
\text { writer. }\end{array}$ & $\begin{array}{l}\text { The feedback I } \\
\text { get from } \\
\text { [resource] is } \\
\text { unnecessarily } \\
\text { harsh. }\end{array}$ & $\begin{array}{l}\text { I feel like I get } \\
\text { a good mix of } \\
\text { praise and } \\
\text { suggestions }\end{array}$ \\
\hline Advisor & 92 & 36.29 & 22.17 & 13.61 & 75.87 \\
\hline Classmate and colleagues & 94 & 39.22 & 20.76 & 18.96 & 76.73 \\
\hline Family and friends & 65 & 38.53 & 12.56 & 3.92 & 66.16 \\
\hline Instructor (not advisor) & 64 & 38.74 & 22.05 & 16.74 & 75.63 \\
\hline Writing group & 34 & 18.33 & 12.07 & 7.25 & 79.45 \\
\hline Editor/reviewer & 27 & 27.21 & 15.92 & 19.5 & 62.11 \\
\hline Writing consultant & 9 & 11.5 & 3.67 & 10.5 & 85.67 \\
\hline
\end{tabular}


The results of this study seem to suggest that, occasional horror stories aside, these participants don't perceive a widespread emotional crisis in humanities advising. But even though advisors score quite well on some indicators, there is plenty to improve on. It is shocking, for example, that even $13 \%$ of students feel their advisors are unnecessarily harsh. We suspect that no advisor would want to hear that they are perceived as not taking their advisees seriously as academic writers. These relatively low numbers of dissatisfaction still leave room for improvement.

\section{Discussion and Limitations}

We recognize that this study contains some limitations. The most important limitation of this study is that the sample may not be representative of all graduate students in the liberal arts program, let alone all graduate students at the university. Local research is always plagued by local conditions. The survey was primarily conducted online by asking liberal arts program directors to forward our email to students to opt in. The responses we received do not proportionately represent the majors in our university: for instance, some departments, like Spanish and Portuguese, are disproportionately represented in our survey. We have also aggregated the graduate student responses for much of the data represented here. This is partially to paint a holistic picture of graduate writing networks, but we recognize that subcategories of student, such as department, discipline, progress towards degree, first-generation status, race, gender, and ethnicity will all impact the graduate writing experience. Also, anecdotally, many humanities graduate students who use our graduate writing groups were reminded in person about the survey. Finally, at the time of this research, the University Writing Center at the researched institution had been offering graduate student services, including sponsored writing groups and individual consultations, for less than a year. The low rate of respondents who reported using a writing consultant will certainly change when the center has established more of a reputation. These local and institutional limitations circumscribe our conclusions for other universities and programs.

Despite its limitations, our study did result in several useful findings. First, it demonstrates that graduate students do form networks to help them with their writing rather than rely exclusively on direction from their advisors. Our study demonstrates that advisors are important, and they rank particularly high among our participants with higher-level writing concerns and academic content, but the graduate students in our study make use of a long list of resources to improve their academic writing. In this way, our study echoes the findings of Tompkins, Bretch, Tucker, Neander, and Swift (2016) when they found that student-peers and family/friend support had an outsized impact on the satisfaction of psychology graduate students. Advisors are important, the authors maintain, but their findings emphasize "the important role of having consistent and diverse social support" (Tompkins et al., 2016, p. 106). While Tompkins et al. (2016) consciously excluded instrumental questions about, for example, how networks "helped you improve your writing skills" (Tenenbaum, Crosby, \& Gliner, 2001), our research suggests that peers and family would have likely been ranked an asset for writing and publishing alongside advisors. In other words, Tompkins et al. (2016) found that advisors played a role, but not an exclusive role, in perceptions 
of graduate student satisfaction and support; likewise, we found that advisors are important but not sufficient to fulfill all the needs graduate students seek from writing support networks.

The graduate students in our study's interviews, freely and without prompting, described the help they got from other sources. Karen valued a friend who was a reader "because she gave me a very external point of view," while her advisor sometimes "cannot see the forest for the trees." Luisa, in our interview group, also valued the perspectives of people who were external to her current program; not only did she seek feedback from friends, but kept up friendships from her masters program for feedback: "I trust their feedback and it's kind of a fresh perspective from people who are not sitting in the same classroom as me every day so they can kind of say, does this in and of itself make sense? That's useful." These comments support the quantitative data in demonstrating that graduate students make use of different networks to help them work through different aspects of their writing. The advisor is not the only source of good writing feedback.

The second conclusion that our research supports is that the graduate students in our study formed very different kinds of relationships with the different sources. Students feel comfortable asking for help from advisors overall, but there are still some of our respondents who felt their advisors didn't take their work seriously, or they still had a hard time asking for help from authority figures. Other resources, especially writing groups, appear to be easier for graduate students to ask for support. The gift-giving reciprocity of these writing groups may be the reason why students feel relatively comfortable asking group members for help and trust them so deeply. A participant in our focus group described a long-term reader's help: "It's not tit for tat, but it goes back and forth." Karen believed that others who were dissertating were the best examples of feedback. There were no writing groups when she did her undergraduate work in Chile and now she loves being with writers who "are experiencing the same process." Peers provide important social ties in addition to giving unique perspectives in writing.

\section{Conclusion}

The humanities graduate students in our study developed rich writing feedback networks organically, and this study is presented primarily as a description of how graduate students find support for their academic writing. However, the research does have practical application for program directors, advisors, and graduate student service providers at the university. These applications can have far-reaching impact on students.

Non-advisor networks are important during graduate school, but may become crucial after the hooding ceremony is over. Advisors and departments set requirements for graduation, but they focus on their own internal mission (e.g. producing a self-sustained program of prestigious scholars) and may quickly lose track of graduated students (Sweitzer, 2009). A newly minted PhD, though, may possess rich networks of support for the post-graduate school world. Boud and Lee (2005) found that after graduate school individuals wove "fellow students first and foremost, but also co-workers, co-researchers and collaborators within and outside the university" (p. 514) into their research and writing practices. Also, Sinclair and Cuthbert (2014), in a meta-study of what factors contribute to post-doctoral productivity, note that most of the research "challenge[s] the 
notion of productivity as an individualized phenomenon... pointing instead to productivity as a networked or inter-dependent phenomenon" (p. 1978). For junior scholars to succeed, they must draw on the social and professional networks they learned to establish in graduate school.

One of the pedagogical responsibilities, then, of graduate programs is to facilitate the nonadvisor networks that will continue to support scholars after they have left graduate school. The participants in our study show that successful graduate students do form networks, but there may be others, especially first-generation and at-risk graduate students, who are even more likely to benefit from specific instruction on how to find and create additional sources of writing feedback to form a rich network. Students may not intuit how to ask for feedback from various sources within their network. Graduate program directors can work glove-in-hand with other parties from graduate student government to the writing center to develop effective networks of support for graduate writers from the very beginning of their practice.

From the onset of a student's graduate education, programs should provide explicit information about how graduate students can and should be using various sources for writing feedback. Program directors, advisors, and others can also benefit from clarifying for themselves what these sources might look like. For example, Eckstein, Evans, Moglen, and Whitener (2017) describe the benefits of their own graduate writing group in concrete terms, and suggest a typology for other writing groups. Another typology by Haas (2014) can be used to correlate expectations of what, exactly, a writing group is and how it operates (cf. Aitchison, 2009; Gardner, 2008; Hixson, Lee, Hunter, Paretti, Matusovich, \& McCord, 2016; Kumar \& Aitchison, 2018; McMurray, 2017; Parker, 2009; Philips, 2012). Advisors can describe what is necessary in the formation and upkeep of effective writing groups, and how to provide feedback to student colleagues that isn't unnecessarily harsh or competitive. Some advisors may choose to sponsor writing groups among their advisees. Graduate program directors can also team with graduate student service providers to create opportunities for training all faculty members, not just those in official advisory roles, in the best practices of giving writing feedback. Humanities graduate programs can create cultures of writing feedback that provide mentorship and peer learning at many levels, setting students up for success in the dissertation and beyond.

\section{Acknowledgements}

This work was supported by a grant from the South Central Writing Center Association. Research was conducted at the University of Texas in Austin, Texas, USA, with the support of the University Writing Center.

\section{References}

Aitchison, C. (2010). Learning together to publish: Writing group pedagogies for doctoral publishing. In C. Aitchison, B. Kamler, \& A. Lee (Eds.), Publishing pedagogies for the doctorate and beyond (pp. 83-100). New York, NY: Routledge. 
Aitchison, C. (2009). Writing groups for doctoral education. Studies in Higher Education, 34(8), 905-916.

Aitchison, C, \& Paré, A. (2012). Writing as craft and practice in the doctoral curriculum. In A. Lee \& S. Danby (Eds.), Reshaping doctoral education: International approaches and pedagogies (pp. 12-25). New York, NY: Routledge.

Athiyaman, A. (1997). Linking student satisfaction and service quality perceptions: The case of university education. European Journal of Marketing, 31(7), 528-540.

Baird, L. L. (1995). Helping graduate students: A graduate adviser's view. New Directions for Student Services, 72, 25-32.

Becher, T. \& Trowler, P. (2001). Academic tribes and territories: Intellectual enquiry and the culture of disciplines. New York, NY: McGraw-Hill Education.

Bieber, J. P., \& Worley, L. K. (2006). Conceptualizing the academic life: Graduate students' perspectives. The Journal of Higher Education, 77(6), 1009-1035.

Boud, D., \& Lee, A. (2005). 'Peer learning' as pedagogic discourse for research education. Studies in Higher Education, 30(5), 501-516.

Catterall, J., Ross, P., Aitchison, C., \& Burgin, S. (2011). Pedagogical approaches that facilitate writing in postgraduate research candidature in science and technology. Journal of University Teaching and Learning Practice, 8(2), 1-10.

Council of Graduate Schools. (2010). Ph.D. completion and attrition: Policies and practices to promote student success. Washington, D.C.: Council of Graduate Schools Ph.D. Completion Project.

Ehrenburg, R.G., Zuckerman, H., Groen, J. A., \& Brucker, S. M. (2009). Educating scholars: Doctoral education in the humanities. Princeton, NJ: Princeton University Press.

Eyres, S. J., Hatch, D. H., Turner, S. B., \& West, M. (2001). Doctoral students' responses to writing critique: Messages for teachers. Journal of Nursing Education, 40(4), 149-155.

Gardner, S. K. (2008). What's too much and what's too little? The process of becoming an independent researcher in doctoral education. The Journal of Higher Education, 79(3), 326350.

Gardner, S. K., \& Barnes, B. J. (2014). Advising and mentoring doctoral students: A handbook. CreateSpace Independent Publishing Platform.

Haas, S. (2014). Pick-n-Mix: A typology of writers' groups in use. In C. Aitchison \& C. Guerin (Eds.), Writing groups for doctoral education and beyond (pp. 30-47). New York, NY: Routledge.

Hedengren, M., \& Lockerd, M. (2017). Tell me what you really think: Lessons from negative student feedback. The Writing Center Journal, 36(1)131-145.

Hixson, C., Lee, W., Hunter, D., Paretti, M., Matusovich, H., \& McCord, R. (2016). Understanding the structural and attitudinal elements that sustain a graduate student writing group in an engineering department. WLN: A Journal of Writing Center Scholarship, 40(5), 18-26.

Kamler, B., \& Thomson, P. (2014). Helping doctoral students write: Pedagogies for supervision. London, UK: Routledge.

Kumar, V., \& Aitchison, C. (2018). Peer facilitated writing groups: A programmatic approach to doctoral student writing. Teaching in Higher Education, 23(3), 360-373.

Lave, J., \& Wenger, E. (1991). Situated learning: Legitimate peripheral participation. Cambridge, UK: Cambridge University Press. 
Lee, A., \& Aitchison, C. (2011). Writing with tensions: Writing for publication during your doctorate. In T. S. Rocco \& T. G. Hatcher (Eds.), The handbook of scholarly writing and publishing (pp. 62-74). San Francisco, CA: John Wiley \& Sons.

Lee, A., \& Boud, D. (2003). Writing groups, change and academic identity: Research development as local practice. Studies in Higher Education, 28(2), 187-200.

Lovitts, B. E. (2001). Leaving the ivory tower: The causes and consequences of departure from doctoral study. Lanham, MD: Rowman \& Littlefield.

McMurray, C. (2017). A Systematic Approach to Graduate Writing Groups: Facilitator, First Meeting, and Feedback Structure. Praxis: A Writing Center Journal, 14(2). Retrieved from http://www.praxisuwc.com/mcmurray-142

Nettles, M. T., \& Millett, C. M. (2006). Three magic letters: Getting to PhD. Baltimore, MD: Johns Hopkins University Press.

North, S. M. (1984). The idea of a writing center. College English, 46(5), 433-446.

Parker, R. (2009). A learning community approach to doctoral education in the social sciences. Teaching in Higher Education, 14(1), 43-54.

Parry, S. (2007). Disciplines and doctorates. Dordrecht, Netherlands: Springer.

Phillips, T. (2012). Graduate writing groups: Shaping writing and writers from student to scholar. Praxis: A Writing Center Journal, 10(1). Retrieved from http://www.praxisuwc.com/phillips-101/

Sweitzer, V. B. (2009). Towards a theory of doctoral student professional identity development: A developmental networks approach. The Journal of Higher Education, 80(1), 1-33.

Tenenbaum, H. R., Crosby, F. J., \& Gliner, M. D. (2001). Mentoring relationships in graduate school. Journal of Vocational Behavior, 59(3), 326-341. http://dx.doi.org/10.1006/jvbe.2001.1804

Tompkins, K. A., Brecht, K., Tucker, B., Neander, L. L., \& Swift, J. K. (2016). Who matters most? The contribution of faculty, student-peers, and outside support in predicting graduate student satisfaction. Training and Education in Professional Psychology, 10(2), 102-108. http://dx.doi.org/10.1037/tep0000115 
